\title{
Description of the Columbia Basin Wind Energy Study (CBWES)
}

\section{LK Berg}

M Pekour

D Nelson

October 2012

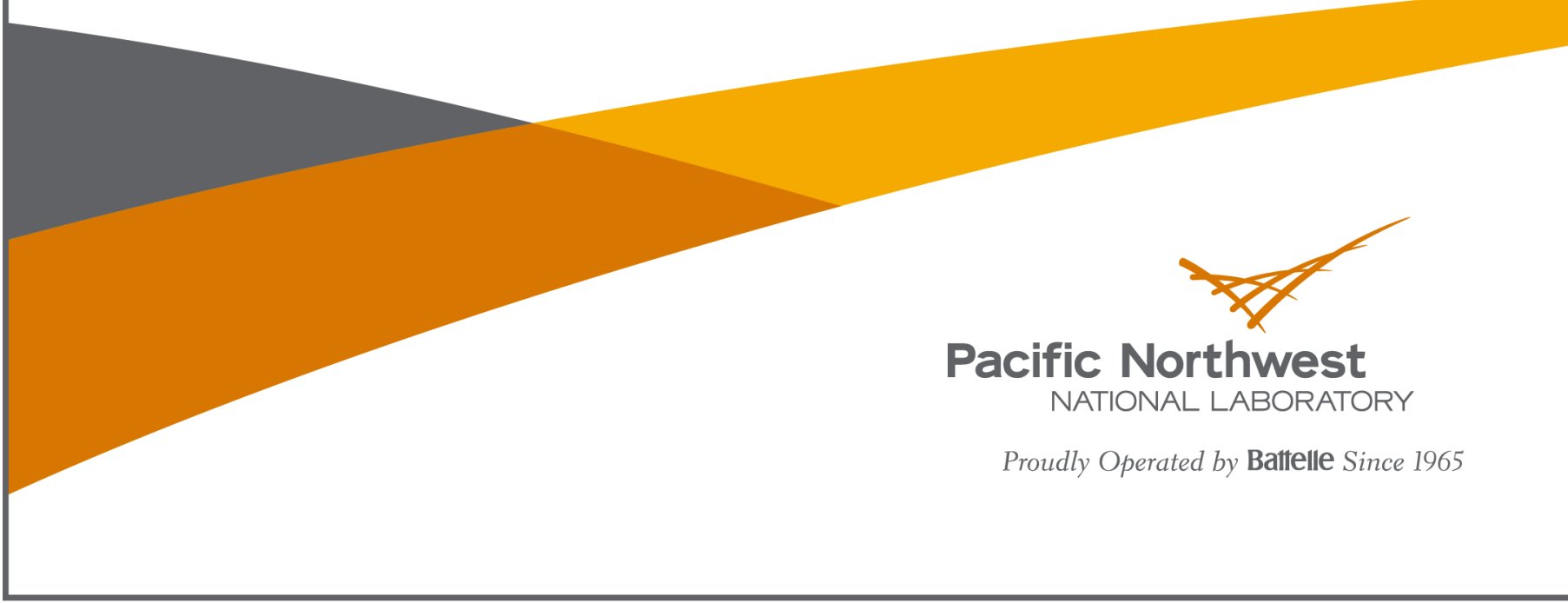




\title{
DISCLAIMER
}

This report was prepared as an account of work sponsored by an agency of the United States Government. Neither the United States Government nor any agency thereof, nor Battelle Memorial Institute, nor any of their employees, makes any warranty, express or implied, or assumes any legal liability or responsibility for the accuracy, completeness, or usefulness of any information, apparatus, product, or process disclosed, or represents that its use would not infringe privately owned rights. Reference herein to any specific commercial product, process, or service by trade name, trademark, manufacturer, or otherwise does not necessarily constitute or imply its endorsement, recommendation, or favoring by the United States Government or any agency thereof, or Battelle Memorial Institute. The views and opinions of authors expressed herein do not necessarily state or reflect those of the United States Government or any agency thereof.

\author{
PACIFIC NORTHWEST NATIONAL LABORATORY \\ operated by \\ BATTELLE \\ for the \\ UNITED STATES DEPARTMENT OF ENERGY \\ under Contract DE-AC05-76RL01830
}

Printed in the United States of America

\author{
Available to DOE and DOE contractors from the \\ Office of Scientific and Technical Information, \\ P.O. Box 62, Oak Ridge, TN 37831-0062; \\ ph: (865) 576-8401 \\ fax: $(865) 576-5728$ \\ email: reports@adonis.osti.gov
}

Available to the public from the National Technical Information Service

5301 Shawnee Rd., Alexandria, VA 22312

ph: (800) 553-NTIS (6847)

email: orders@ntis.gov <http://www.ntis.gov/about/form.aspx>

Online ordering: http://www.ntis.gov 


\section{Description of the Columbia Basin Wind Energy Study (CBWES)}

LK Berg

M Pekour

D Nelson

October 2012

Prepared for

the U.S. Department of Energy

under Contract DE-AC05-76RL01830

Pacific Northwest National Laboratory

Richland, Washington 99352 


\section{Summary}

The purpose of this technical report is to provide background information about the Columbia Basin Wind Energy Study (CBWES). This study, which was supported by the U.S. Department of Energy's Wind and Water Power Program, was conducted from November 16, 2010 through March 21, 2012 at a field site in northeastern Oregon. The primary goal of the study was to provide profiles of wind speed and wind direction over the depth of the boundary layer in an operating wind farm located in an area of complex terrain. Measurements from propeller and vane anemometers mounted on a $62-\mathrm{m}$ tall tower, Doppler sodar, and radar wind profiler (RWP) were combined into a single data product to provide the best estimate of the winds above the site during the first part of CBWES. An additional goal of the study was to provide measurements of turbulence kinetic energy (TKE) near the surface. To address this specific goal, sonic anemometers were mounted at two heights on the 62-m tower on April 23, 2011. Prior to the deployment of the sonic anemometers on the tall tower, a single sonic anemometer was deployed on a short tower, $3.1 \mathrm{~m}$ tall, that was located just to the south of the radar wind profiler. Data from the radar wind profiler, as well as the wind profile data product are available from the Atmospheric Radiation Measurements (ARM) Data Archive (http://www.arm.gov/data/campaigns). Data from the sonic anemometers are available from the authors. 


\section{Acknowledgments}

This research was supported by the U.S. Department of Energy's Office of Energy Efficiency and Renewable Energy, Wind and Water Power Program. The RWP deployed at CBWES was provided by the ARM Program and the propeller and vane anemometer data was provided by Bonneville Power Administration (BPA). John Lodahl (BPA) assisted with the selection of the field site. Jim Barnard, Jeremy Brandstetter, Victor Morris, Rob Newsom, and Jack Vannice helped to set-up and tear-down the field site. Access to the radio tower was granted by New Northwest Broadcasters, LLC and access to the property around the CBWES field site was granted by Tony and Peggy Raymond. 


\title{
Acronyms and Abbreviations
}

\author{
BPA Bonneville Power Administration \\ CBWES Columbia Basin Wind Energy Study \\ m meter \\ QC quality control \\ RWP radar wind profiler \\ TKE turbulence kinetic energy
}




\section{Contents}

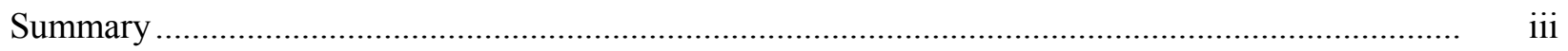

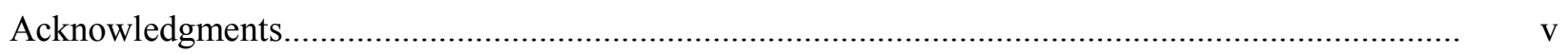

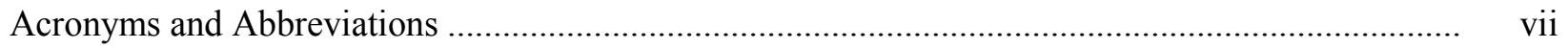

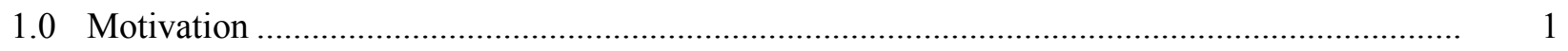

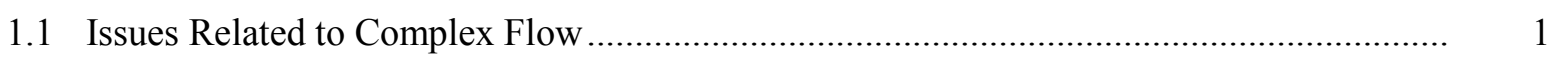

1.2 Traditional and Nontraditional Data Sources ............................................................... 2

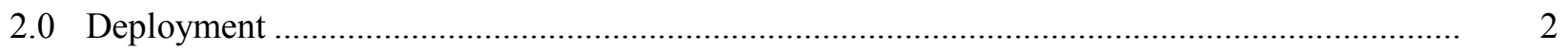

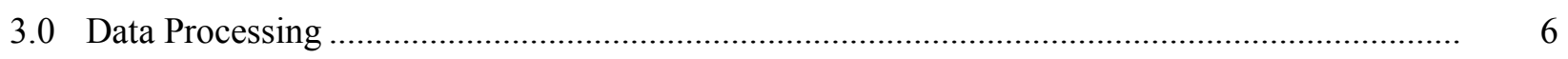

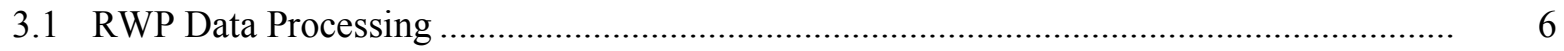

3.2 Doppler Sodar Data Processing .............................................................................

3.3 Sonic Anemometer Date Processing ........................................................................... 8

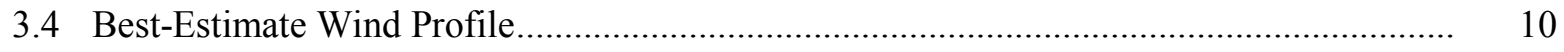

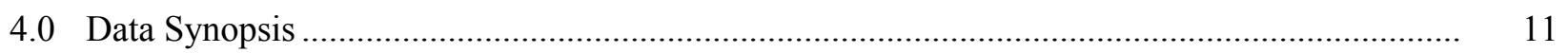

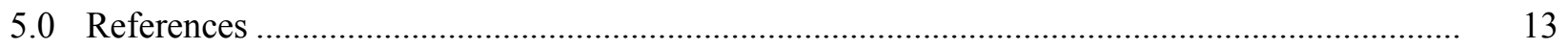




\section{Figures}

1. Location of CBWES field site (black dot) and terrain elevation (colors).

2. Panoramic view from the location of the RWP deployed at the CBWES site looking (a) north (b) west (c) south (d) east. Note the proximity of the wind turbine towards the southeast. The base of the 62-m tower is visible in (c) and (d).

3. Sonic anemometers deployed at the top (left) and mid-way up (right) on the radio tower during CBWES.

4. Wind speed distributions (left) and wind direction (right) measured by the RWP (lowest range gate of $146 \mathrm{~m}$ ) and by the tower (top level of $62 \mathrm{~m}$ )

5. Distributions of wind speed measured by the sodar (lowest useful range gate of $80 \mathrm{~m}$ ) and by the tower anemometer $(62 \mathrm{~m})$. Red circles (sodar) and magenta dots (tower) depict distribution based on common times.

6. Number of occurrences of half-hourly averaged wind direction measured at $62 \mathrm{~m}$ (black), $45 \mathrm{~m}$ (red), and $31 \mathrm{~m}$ (blue) above ground on the tall tower using data collected from August 2008 through November 2011.

7. Time-height cross section of wind speed (top colors) and wind direction (bottom colors), along with wind speed (top-right axis, black) and wind direction (bottom-right axis, black) measured by the propeller and vane anemometer at $62 \mathrm{~m}$ (right axes). White areas indicate missing data.

\section{Tables}

1. Instruments deployed during CBWES............................................................................. 5

2. Parameters in CBWES sonic anemometer data files. ........................................................... 9

3. QC flags used in sonic anemometer monthly files................................................................ 10

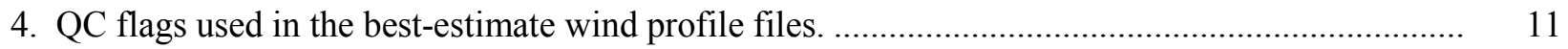




\subsection{Motivation}

Understanding the complex flow patterns within several hundred meters of the surface is critical for evaluating the wind energy potential of a given site, as well as providing better forecasts of wind power production. Schreck et al. (2008) provide an overview of many of the relevant issues, including the need for better models and improved data sets while Marquis et al. (2011) highlight the importance of improved wind and power forecasts for the industry.

There are large amounts of data routinely collected by existing meteorological networks. Most observations of wind speed are made at the standard measurement height of $10 \mathrm{~m}$ above the surface. In contrast, the wind power industry is particularly interested in measurements of wind speed through the hub height (nominally 80-100 $\mathrm{m}$ above the surface) to the top of the rotor, which can be as high as $150 \mathrm{~m}$. There have been a number of intensive field campaigns that include measurements of wind speed and wind direction over the depth of the planetary boundary layer (e.g. Allwine et al. 2002, Doran et al. 2002, and Poulos et al. 2002). These studies, however, are generally of limited duration or were located in areas that are not optimal for wind power development, making them less than ideal for issues related to resource characterization.

Within the wind power industry, yearlong (or longer) data sets are routinely gathered to better understand the wind-energy potential of a given location and to secure financing for a development project. These data sets include tall tower measurements that are extrapolated to the approximate hub-height winds and/or the deployment of remote sensing instruments such as sodars. However, data from these studies are generally considered to be propriety and are not shared across the wind energy or scientific community.

The Columbia Basin Wind Energy Study (CBWES) was a U.S. Department of Energy (DOE) sponsored study designed to address some of these shortcomings, and to provide measurements of wind speed and wind direction over a large portion of the planetary boundary layer. The CBWES site was selected because of its location in complex terrain, as well as the proximity to the Stateline Wind Energy Center. This facility is located in Umatilla County, Oregon and Walla Walla County, Washington. It includes 454 660-kW Vestas V-47 turbines (http://www.nexteraenergyresources.com/content/where/portfolio/pdf/stateline.pdf).

\subsection{Issues Related to Complex Flow}

The complex topography of the CBWES site and surrounding area make it a useful data set for studying issues related to complex flow and inflow to the turbines (including the amount of turbulence). The field site is located near the summit of a north-facing slope on the southern edge of the Columbia Basin. Ideally, additional instruments or those with scanning capability would be deployed to better quantify the complex three-dimensional flow over such a site. There are, however, a number of features that are evident in the single profile of data collected using the instruments deployed at the CBWES site. 


\subsection{Traditional and Nontraditional Data Sources}

Traditional sources of meteorological data, such as those maintained by the National Weather Service, have not been designed to meet the needs of the wind-energy industry. In particular, conditions at the hub height and over the rotor plane are directly linked to the power production by a wind turbine but could bear little resemblance to the wind measured at $10 \mathrm{~m}$ above the ground. Nontraditional data sources can be used to augment existing data networks, providing additional observations of the winds above the surface, particularly in regions that are otherwise data sparse. One of the goals of CBWES was to test retrievals of spatially and temporally varying wind fields measured using National Weather Service WSR88-D radars (Fast et al. 2008). The CBWES field site was located approximately $30 \mathrm{~km}$ north of the Pendleton, Oregon WSR88-D and the data collected during the study has been used to evaluate the utility of the retrieved wind field (Newsom et al. 2012).

\subsection{Deployment}

The CBWES site was located on a northeast-facing slope of a large ridge near the WashingtonOregon border (Figure 1). As shown in a series of photos taken from the location of the radar wind profiler (RWP), the region was devoid of trees and had only limited vegetation to the north, east, and west (Figure 2). The area to the south of the site consisted of a dry-land wheat fields. In addition, some of the State Line Wind Energy Center turbines are visible in the pictures. A number of different in situ and remote sensing instruments were deployed during various periods of CBWES and are listed in Table 1. Prior to CBWES, Bonneville Power Administration (BPA) installed propeller and vane anemometers on an existing 62-m tall radio tower located at the site. BPA records 10-minute averages of wind speed and wind direction that is then posted to a public website. During the first half of the CBWES, a Vaisala $915 \mathrm{MHz}$ RWP was provided by the U.S. DOE's Atmospheric Radiation Measurement Climate Research Facility. The RWP was configured to use only its low-power setting in order to apply a range gate spacing of $57 \mathrm{~m}$, the finest spacing possible. Due to the potential of ground clutter from the radio tower, the RWP was operated in three-beam mode. A Scintec Doppler sodar was also deployed. The sodar was operated using 10-m range gate spacing and a maximum range of $400 \mathrm{~m}$. An averaging period of 15 minutes was used. In contrast to the RWP, the sodar was in the field during the entire duration of the study. Unfortunately, the sodar data quality was relatively poor, most likely due to ambient noise at the site and technical issues with the sodar itself.

Sonic anemometers (ATI SATI/3K) were deployed during selected periods of CBWES. Due to logistical issues associated with mounting sonic anemometers on the radio tower, a single sonic anemometer was operated on a small tripod tower for the first period of the study (Table 1). While not ideal, the operation of the single sonic anemometer does provide an estimate of turbulence over the site. After April 23, 2011, sonic anemometers were mounted at heights of 30 and $60 \mathrm{~m}$ on the radio tower (Figure 3). Two sonic anemometers were mounted at the top level on booms $3.5 \mathrm{~m}$ long pointing to the southeast and southwest. This arrangement was selected to give redundancy at the top level in the event of a failure of one of the systems. All of the remaining instrumentation was removed from the field on March 21, 2012.

This particular suite of instruments was selected to provide profiles of wind speed and direction from the surface to well above the area swept by the blades of a wind turbine. The data from the sonic 
anemometers provide an estimate of the atmospheric stability and turbulence intensity from near the surface to $60 \mathrm{~m}$ above the ground. As will be described in Section 3, data from the various instrument platforms were combined to provide the best estimate of the wind profile.

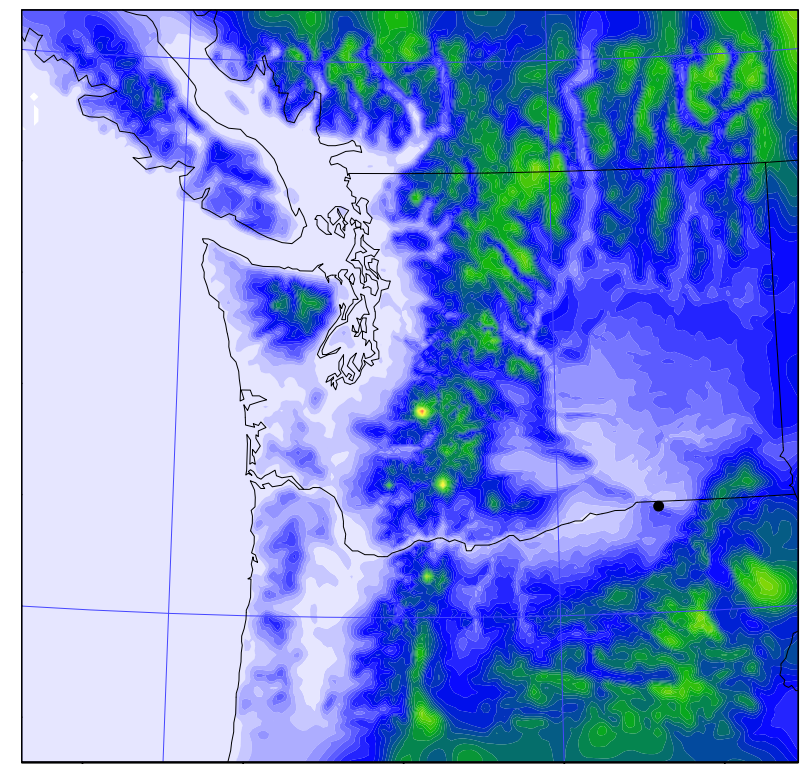

Figure 1. Location of CBWES field site (black dot) and terrain elevation (colors). 
a.

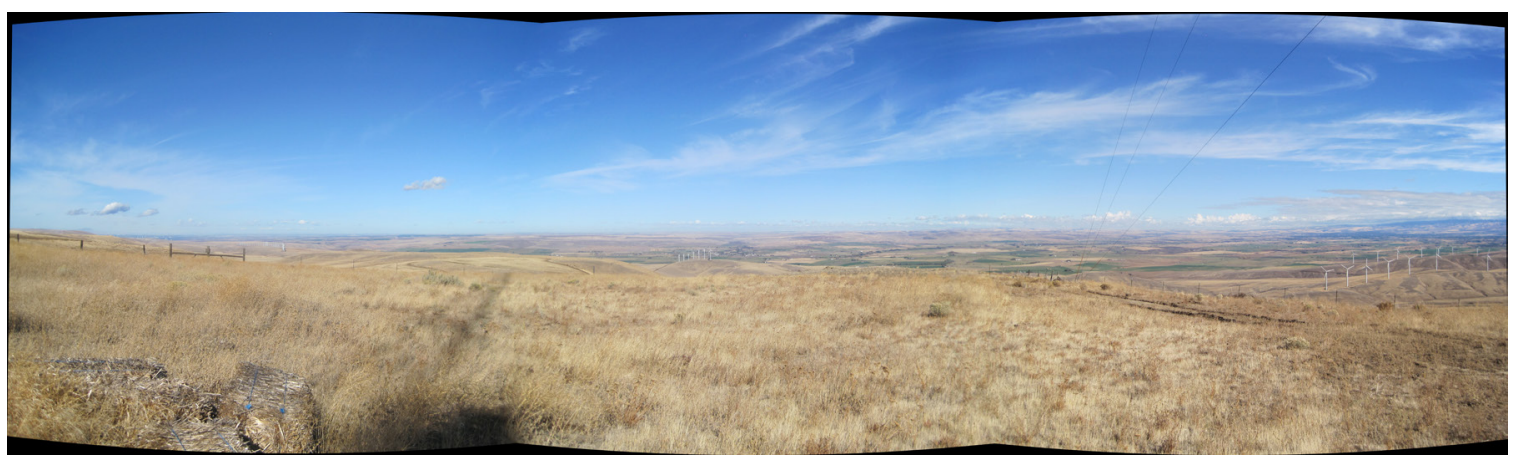

b.

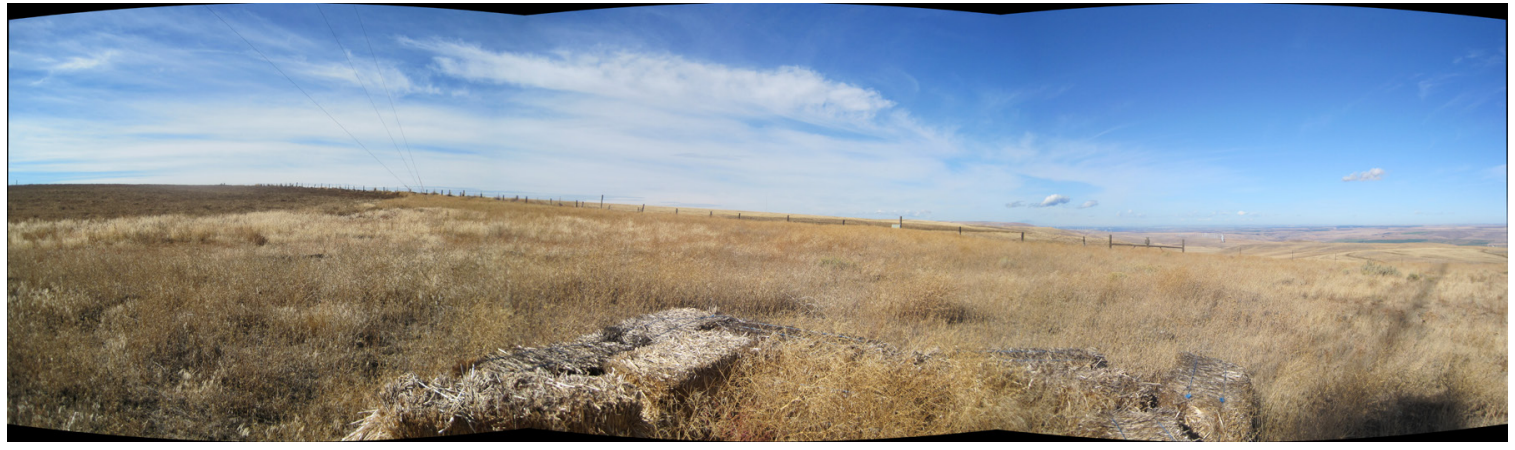

c.

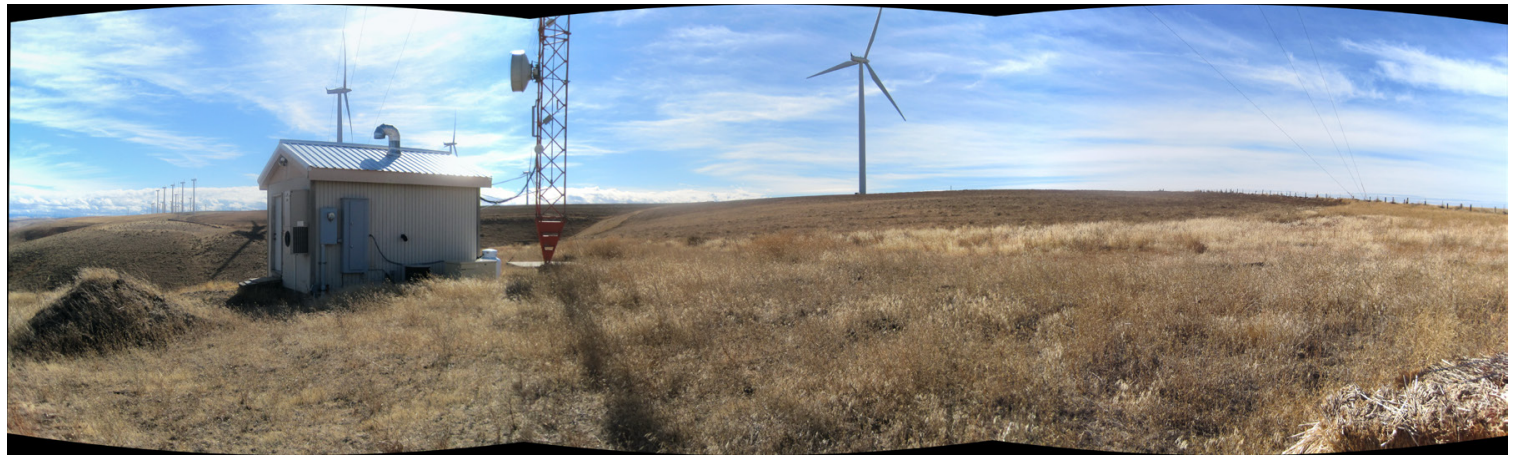

d.

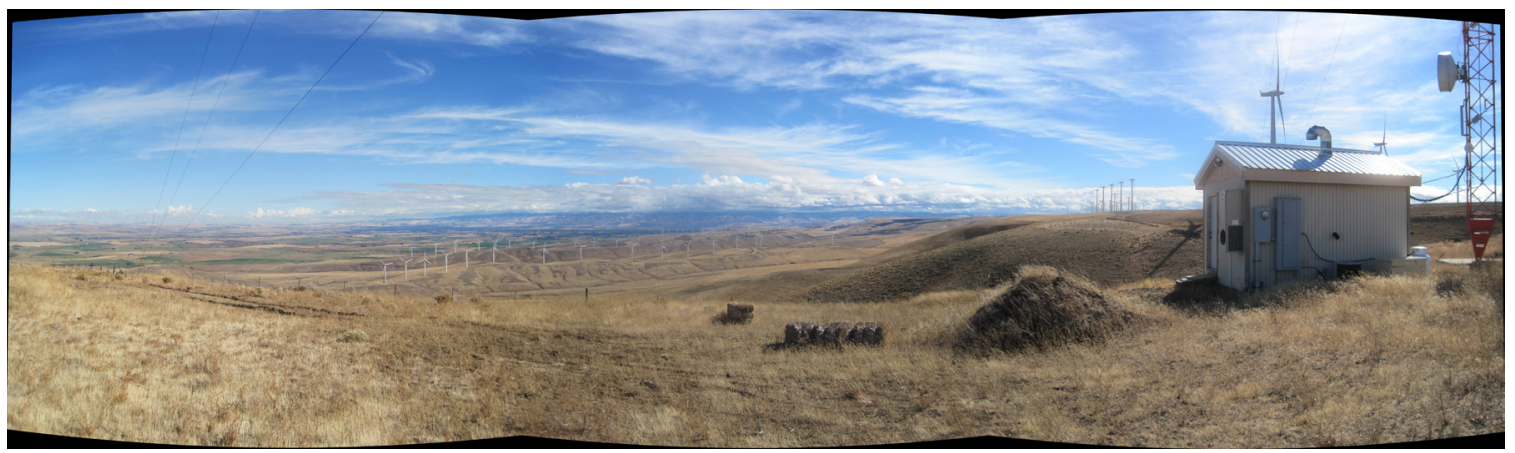

Figure 2. Panoramic view from the location of the RWP deployed at the CBWES site looking (a) north (b) west (c) south (d) east. Note the proximity of the wind turbine towards the southeast. The base of the 62-m tower is visible in (c) and (d). 
Table 1. Instruments deployed during CBWES.

\begin{tabular}{|c|c|c|c|c|c|}
\hline Instrument & $\begin{array}{l}\text { Deployment } \\
\text { period }\end{array}$ & $\begin{array}{l}\text { Nominal } \\
\text { heights } \\
\text { (m AGL) }\end{array}$ & Data collected & $\begin{array}{l}\text { Initial } \\
\text { averaging } \\
\text { interval } \\
\text { (minutes) }\end{array}$ & $\begin{array}{l}\text { Wind direction } \\
\text { correction or } \\
\text { sonic boom } \\
\text { orientation } \\
\text { (degrees) }\end{array}$ \\
\hline $915 \mathrm{MHz}$ RWP & $\begin{array}{l}11 / 16 / 10- \\
5 / 24 / 11\end{array}$ & $\begin{array}{l}89-1462 \\
25 \text { range gates }\end{array}$ & $\begin{array}{l}\text { Spectra, } \\
\text { consensus } \\
\text { averaged winds }\end{array}$ & 30 & 25 \\
\hline Doppler sodar & $\begin{array}{l}12 / 4 / 10- \\
3 / 21 / 12\end{array}$ & $\begin{array}{l}30-410 \\
40 \text { range gates }\end{array}$ & $\begin{array}{l}\text { Raw, averaged } \\
\text { wind profiles }\end{array}$ & 15 & 24 \\
\hline \multirow[t]{4}{*}{$\begin{array}{l}\text { Sonic } \\
\text { anemometer }\end{array}$} & $\begin{array}{l}1 / 21 / 11- \\
4 / 18 / 11\end{array}$ & 3.1 & $\begin{array}{l}\text { Raw sonic } 10 \mathrm{~Hz} \text {, } \\
\text { calculated } \\
\text { turbulence data }\end{array}$ & 30 & 174 \\
\hline & $\begin{array}{l}4 / 23 / 11- \\
3 / 21 / 12\end{array}$ & 30 & $\begin{array}{l}\text { Raw sonic } 10 \mathrm{~Hz} \text {, } \\
\text { calculated } \\
\text { turbulence data }\end{array}$ & 30 & 172 \\
\hline & $\begin{array}{l}4 / 23 / 11- \\
3 / 21 / 12\end{array}$ & 60 & $\begin{array}{l}\text { Raw sonic } 10 \mathrm{~Hz} \text {, } \\
\text { calculated } \\
\text { turbulence data }\end{array}$ & 30 & 172 \\
\hline & $\begin{array}{l}4 / 23 / 11- \\
3 / 21 / 12\end{array}$ & 60 & $\begin{array}{l}\text { Raw sonic } 10 \mathrm{~Hz} \text {, } \\
\text { calculated } \\
\text { turbulence data }\end{array}$ & 30 & 52 \\
\hline $\begin{array}{l}\text { Propeller and } \\
\text { vane } \\
\text { anemometers }\end{array}$ & Permanent & $30,44,62$ & $\begin{array}{l}\text { Data retrieved } \\
\text { from publically } \\
\text { available archive }\end{array}$ & 10 & \\
\hline
\end{tabular}

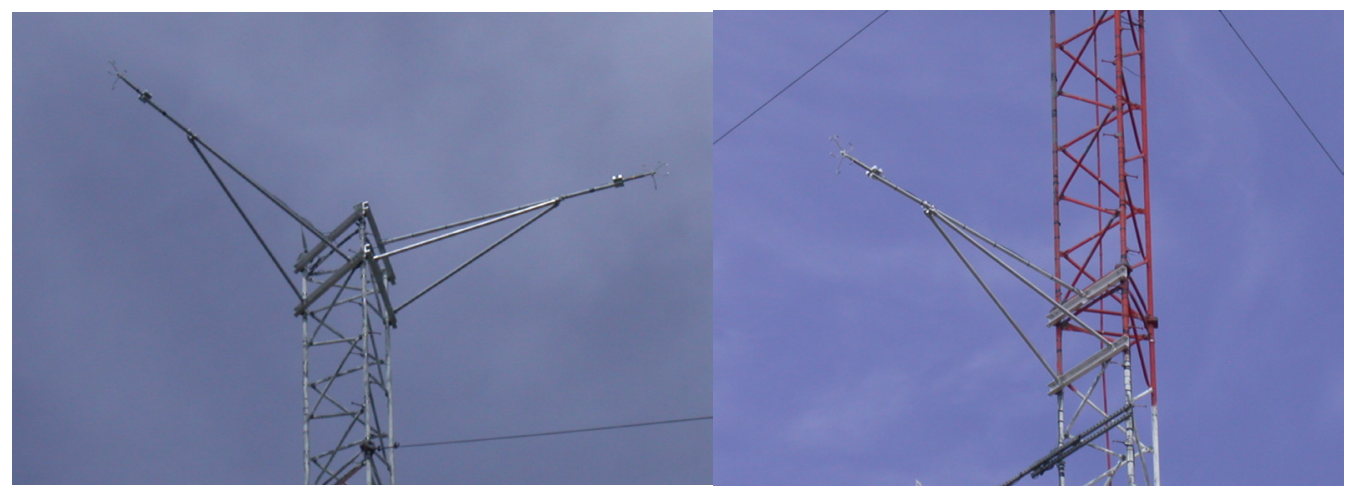

Figure 3. Sonic anemometers deployed at the top (left) and mid-way up (right) on the radio tower during CBWES. 


\subsection{Data Processing}

\subsection{RWP Data Processing}

The processing of the RWP data required a number of steps to ensure data quality. The methods applied were designed to be conservative, meaning only the highest-quality data was retained in the RWP time series. Careful examination of the data from the RWP revealed that it was affected by ground and intermittent clutter from the tower, tower guy wires, and possibly the rotating blades of the nearest turbine. It is important to note that clutter will affect different range gates in different beams so if the data were processed in the standard way, estimates of wind speed and wind direction from a number of different range gates would be invalidated. During CBWES, the lowest range gate in particular was always contaminated by internal antenna reflections and/or switching noise and was discarded.

Data processing was based on the standard output of the RWP software (LAP-XM ver. 4.1) wind consensus data, which contains wind velocity, wind direction, and three wind components: $u$ (east-west), $\mathrm{v}$ (north-south), and w (vertical). It should be noted that the wind directions are relative to the RWP antenna and do not coincide with true geographic directions. A number of additional quality checks were applied to the data. These checks were based on the measured wind speed and direction using the BPA propeller and vane anemometers, which were located on the radio tower and treated as truth during data processing. Outliers in the RWP data were identified using a median filter with \pm 2 data points in the vicinity (in both time and height) of the observation of interest. Small gaps (defined as less than four hours in time or five range gates in height) in the filtered data were filled using cubic spline

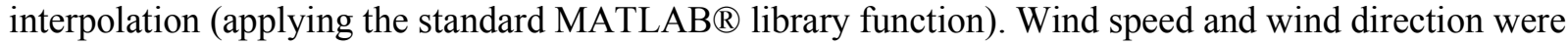
recomputed from the two filtered/filled components and wind direction was corrected for the orientation of the radar antenna. Distributions of wind speed and wind direction measured at a height of $62 \mathrm{~m}$ above ground and at the lowest useful RWP range gate $(146 \mathrm{~m})$ are presented in Figure 4. Similar shapes of the distributions suggest that the final RWP data are not biased toward low wind due to clutter or selective sampling issues and that there is good agreement between the tower and RWP data. 

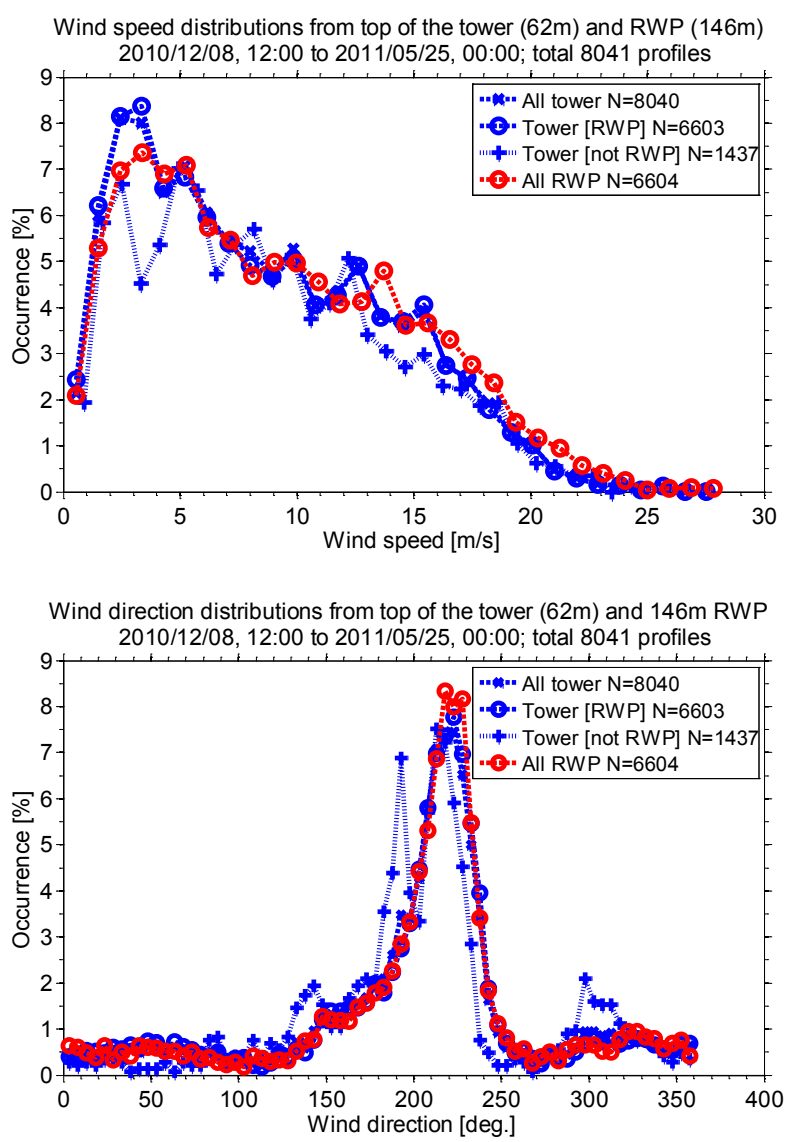

Figure 4. Wind speed distributions (left) and wind direction (right) measured by the RWP (lowest range gate of $146 \mathrm{~m}$ ) and by the tower (top level of $62 \mathrm{~m}$ ).

\subsection{Doppler Sodar Data Processing}

The data from the Doppler sodar was processed to ensure high-quality data. The sodar was operated in five beam coded pulse mode with 39 range gates and 10-m spacing, nominally covering heights from 30 to $410 \mathrm{~m}$. The sodar data were reprocessed from the raw files using the latest available software (APRun version 1.41) with the lowest internal QC (quality control) thresholds into 10-minute averages. A number of additional checks were performed on the two wind components (east-west and north-south) separately. These checks were based on the wind speed and direction measured using the BPA propeller and vane anemometers located on the radio tower. Small gaps of less than two hours or $100 \mathrm{~m}$ in the filtered data were filled using cubic spline interpolation (applying the standard MATLAB ${ }^{\circledR}$ library function). The two velocity components were averaged to the common averaging interval of 30 minutes used for all of the CBWES data, and the wind speed and wind direction were re-created from the two filtered/filled/averaged components. Finally, the wind direction was corrected for the sodar antenna orientation. The lowest five range gates of the sodar data were so compromised by ground clutter that they were discarded before further processing. Distributions of wind speed measured by the tower anemometer mounted at $62 \mathrm{~m}$ and from $80 \mathrm{~m}$ above ground from the final sodar data set are shown in Figure 5 . The sodar data are clearly biased toward lower wind speeds. This is not a case of a bias in the 
measurements, but rather is caused by selective sampling by the sodar itself. Wind-generated noise depends on the wind speed, and as the wind speed increases, more sodar signals are drowned out in the ambient noise leading to more data being lost.

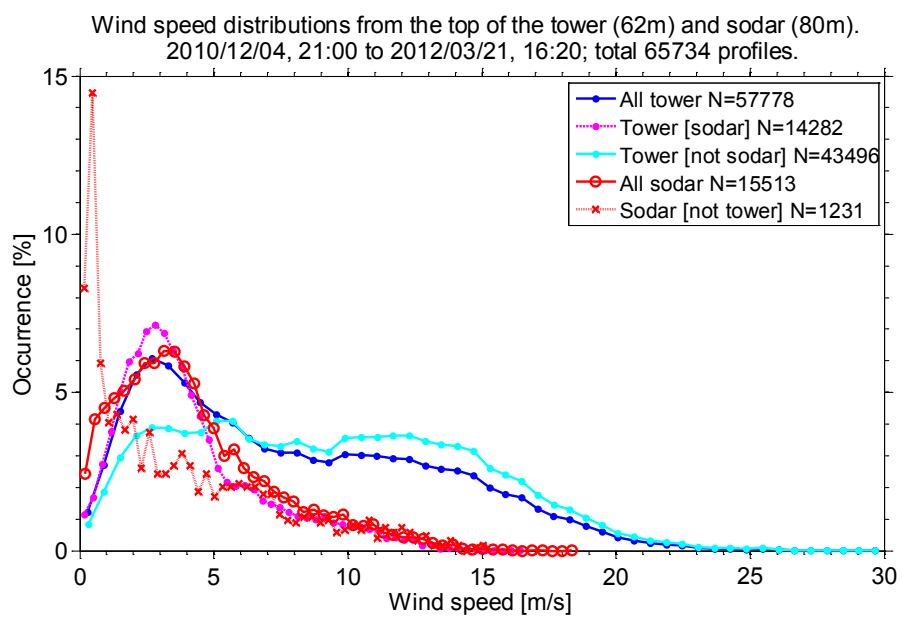

Figure 5. Distributions of wind speed measured by the sodar (lowest useful range gate of $80 \mathrm{~m}$ ) and by the tower anemometer $(62 \mathrm{~m})$. Red circles (sodar) and magenta dots (tower) depict distribution based on common times.

Sodar operation was significantly impeded by reflections from local structures (clutter), ambient noise, and noise generated by wind in the surrounding objects (security fence, tower, tower guy wires, etc.). The acoustic enclosure of the sodar was identified as one possible issue. An additional fence around the sodar antenna was constructed from straw bales, but the sodar performance was only marginally improved, most likely because it did not protect the antenna from noise generated by the tower and/or guy wires higher than the sodar enclosure. Additional reprocessing of the sodar data was also investigated, but proved impractical. The averaged Doppler spectra were pulse coded and averaged over approximately 45 seconds. These signals contain many overlapping features that are averaged together (pulse-coded signals, pulse-coded clutter, random ambient noise, wind-generated noise, etc.) making additional analysis of the spectra quite difficult.

\subsection{Sonic Anemometer Date Processing}

Data from the sonic anemometers were processed using standard methods. After preliminary data checks, the raw sonic anemometer data were processed into chunks of 30-minute duration to produce estimates of the main turbulence parameters, including: sensible heat flux, momentum flux, friction velocity, turbulence kinetic energy (TKE), and Obukhov length. The 30-minute data were passed through a second set of checks and stored in monthly data files, which are available from the authors. These files are simple ASCII files and contain no headers or column names (the columns are defined in Table 2 and the associated readme file), while QC flags used in the sonic anemometer data files are listed in Table 3.

Performance of the sonic anemometers was affected by radio interference from the telecommunications equipment on the radio tower in two ways. First, the sonic anemometer electronics produced spurious/noisy data during periods with large amounts of telecommunications activities. Second, there was data loss associated with the radio modem data transmissions. Other sources of missing 
data include instances when there was rain, dew, or icing on the sensor head. Raw $(10 \mathrm{~Hz})$ sonic anemometer data, along with the wind and temperature power spectra were manually screened for periods when the data were compromised and these periods were discarded.

Table 2. Parameters in CBWES sonic anemometer data files.

\begin{tabular}{|c|c|c|c|}
\hline Column number & Parameter & Representation, units & Comment \\
\hline 1 & year & 4 digit & \\
\hline 2 & month & 2 digit & \\
\hline 3 & day & 2 digit & \\
\hline 4 & hour & 2 digit & \\
\hline 5 & minute & 2 digit & start time, usually 00 or 30 \\
\hline 6 & fractional day of year & & $\begin{array}{l}\text { for January } 1 \text {, it is between } \\
1.0 \text { and } 2.0\end{array}$ \\
\hline 7 & wind speed & $\mathrm{ms}^{-1}$ & \\
\hline 8 & wind direction & $\operatorname{deg}$ & \\
\hline 9 & stdev of wind direction & $\operatorname{deg}$ & \\
\hline 10 & mean u component & $\mathrm{ms}^{-1}$ & $\begin{array}{l}\text { along boom, as reported } \\
\text { by ATI sonic }\end{array}$ \\
\hline 11 & mean v component & $\mathrm{ms}^{-1}$ & $\begin{array}{l}\text { cross boom, as reported by } \\
\text { ATI sonic }\end{array}$ \\
\hline 12 & mean w component & $\mathrm{ms}^{-1}$ & vertical, positive-upward \\
\hline 13 & vertical angle & deg & \\
\hline 14 & stdev of vertical angle & deg & \\
\hline 15 & sonic temperature & $\mathrm{K}$ & $\begin{array}{l}\text { as reported by ATI sonic, } \\
\text { no corrections; or } \\
\text { converted from reported } \\
\text { speed of sound }\end{array}$ \\
\hline 16 & $\begin{array}{l}\text { variance of sonic } \\
\text { temperature }\end{array}$ & $\mathrm{K}^{2}$ & \\
\hline
\end{tabular}


Table 2. (contd)

\begin{tabular}{llll}
\hline Column Number & Parameter & Representation, units & Comment \\
\hline 17 & sensible heat flux & $\mathrm{Wm}^{-2}$ & $\begin{array}{l}\text { using "sonic temperature," } \\
\text { specific heat capacity at } \\
\text { "sonic temperature" and } \\
50 \% \mathrm{RH}\end{array}$ \\
\hline 18 & & $\begin{array}{l}\text { using moist air density at } \\
\text { "sonic temperature" and } \\
50 \% \mathrm{RH}\end{array}$ \\
\hline 19 & dynamic momentum flux & $\mathrm{kg} /\left(\mathrm{ms}^{-2}\right)$ & \\
\hline 20 & & $\mathrm{~ms}^{-1}$ & \\
\hline 21 & friction velocity & $\mathrm{m}^{2} \mathrm{~s}^{-2}$ & using "sonic temperature" \\
\hline 22 & TKE & $\mathrm{m}$ & see QC flag table \\
\hline
\end{tabular}

Table 3. QC flags used in sonic anemometer monthly files.

\begin{tabular}{lll}
\hline QC code & Criteria & Data affected \\
\hline 1 & No processed data file & all data are $9.999 \mathrm{e}+99$ \\
\hline 2 & $\begin{array}{l}\text { Number of measurements for u, } \mathrm{v}, \\
\text { w, or T is below } 2 / 3 \text { of nominal } \\
\text { value (for 30-minute average at } \\
10 \mathrm{~Hz} \text { the threshold is } 12000)\end{array}$ & \\
& $\begin{array}{l}\text { Value of friction velocity is beyond } \\
\text { reasonable range of } 0.15 \text { to } 5 \mathrm{~m} / \mathrm{s}\end{array}$ & $\begin{array}{l}\text { Temperature variance and all } \\
\text { "turbulent" values are set to } \\
9.999 \mathrm{e}+99\end{array}$ \\
\hline 3 & $\begin{array}{l}\text { Sensible heat flux is not within } \\
\text { reasons }\left(-200 \text { to } 1000 \mathrm{~W} / \mathrm{m}^{\wedge} 2\right)\end{array}$ & $\begin{array}{l}\text { Temperature and all "turbulent" } \\
\text { values are set to } 9.999 \mathrm{e}+99\end{array}$ \\
\hline 4 & $\begin{array}{l}\text { Vertical angle is out of reason }(+/-15 \\
\text { deg) }\end{array}$ & All data are $9.999 \mathrm{e}+99$ \\
\hline 5 & $\begin{array}{l}\text { Large temperature variance }(>1.0 \\
\text { deg^2) }\end{array}$ & $\begin{array}{l}\text { Temperature and all "turbulent" } \\
\text { values are set to } 9.999 \mathrm{e}+99\end{array}$ \\
\hline 6 & $\begin{array}{l}\text { The raw wind data }(10 \mathrm{~Hz}) \text { do not } \\
\text { look good (manual screening) }\end{array}$ & All data are $9.999 \mathrm{e}+99$ \\
\hline 7 & $\begin{array}{l}\text { The raw temperature data }(10 \mathrm{~Hz}) \text { do } \\
\text { not look good (manual screening) }\end{array}$ & $\begin{array}{l}\text { All temperature and turbulence data } \\
\text { are } 9.999 \mathrm{e}+99\end{array}$ \\
\hline 8 & $\begin{array}{l}\text { Too many missed values or spikes } \\
\text { (manual screening) }\end{array}$ & All data are $9.999 \mathrm{e}+99$ \\
\hline 9 & & \\
\hline
\end{tabular}

\subsection{Best-Estimate Wind Profile}

Data from the tower, sodar, and RWP were combined together into a single best estimate of the wind profile above the CBWES site. The data from each instrument were averaged and aligned to a common 
time base (30-minute averaging, starting at 00 and 30 minutes of every hour). The data have been stored in ASCII comma separated files: One file for wind speed, one for wind direction, and one for QC flags (defined in Table 4). The data files are available for download at http://www.arm.gov/campaigns/osc2010ewwes. The first line of every file contains a simple heading, with column names like "year" or "height above ground" (height of the propeller and vane anemometer or center of profiling instrument range gate). The time stamp in the first six columns corresponds to the beginning of the averaging interval in UTC; "epoch" (sixth column) is the fractional day since the beginning of time (0000 0000 00:00:00). All missing, bad, or removed data were replaced with a placeholder of -9999 .

Table 4. QC flags used in the best-estimate wind profile files.

\begin{tabular}{ll}
\hline QC flag & Meaning \\
\hline 0 & Originally measured data \\
\hline 1 & Interpolated data \\
\hline 2 & $\begin{array}{l}\text { Outlier, originally measured, but removed and not } \\
\text { interpolated }\end{array}$ \\
\hline 3 & Not measured, not interpolated \\
\hline
\end{tabular}

\subsection{Data Synopsis}

While the majority of the instrumentation was deployed only during CBWES, the BPA anemometers were mounted on the 62-m tall radio tower in August 2008. Thus, the propeller and vane anemometer data provides multi-year observations of wind speed and wind direction at three levels on the tower that can be used to place the CBWES measurements into a broader context. The predominate wind direction observed at all altitudes of the tall tower is southwesterly (Figure 6). The average wind speed measured at the site between August 2008 and November 2011 was 7.4, 7.2, 7.0 ms ${ }^{-1}$, at 62, 45, and $31 \mathrm{~m}$ above ground, respectively. This corresponds to a wind power class of four (Elliott et al. 1986). The propeller anemometer data has not been screened for conditions when the anemometers were downwind of the tower. Given the very low frequency of occurrence of northeasterly winds this is not likely to have an impact on the simple analysis presented here. Conditions observed during CBWES were consistent with the wind climatology. The predominate wind direction during the deployment was from the southwest, and the average wind speed was found to be $7.7 \mathrm{~ms}^{-1}$, as measured by the anemometer mounted at $62 \mathrm{~m}$ above the ground. 


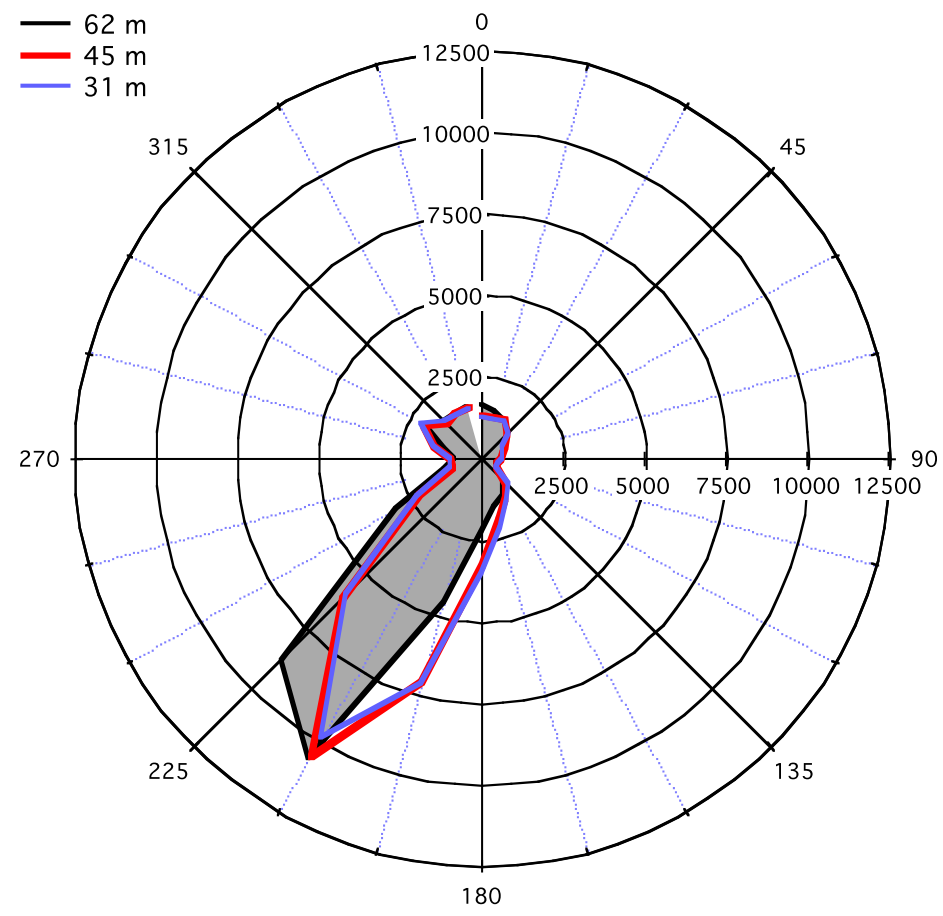

Figure 6. Number of occurrences of half-hourly averaged wind direction measured at $62 \mathrm{~m}$ (black), $45 \mathrm{~m}$ (red), and $31 \mathrm{~m}$ (blue) above ground on the tall tower using data collected from August 2008 through November 2011.

As described in Section 3.2, the performance of the Doppler sodar during CBWES was generally poor. Due to these issues, the sodar data has generally been excluded from the data product. This is particularly unfortunate because the sodar data fills an important height range above the radio tower and below the lowest RWP range gates. These issues also lead to the truncation of the data product to only the periods of time that the RWP was operational at the site. As an example of the data product, time-height cross-sections of the wind speed and wind direction are shown in Figure 7. Clearly, wind speed measured at the site is highly variable and subject to frequent ramp events (relatively large changes of wind speed over a short period of time) during the CBWES study. There are also a number of occasions in December 2011 and January 2011 that the observed wind speed was quite small for a period of days. In addition to the time-height cross section shown in Figure 7, the time series measured using the propeller and vane anemometer $62 \mathrm{~m}$ above the ground has also been included. Additional analysis of the CBWES data can be found in Berg et al. 2013 (which is in preparation as of the writing of this report). 

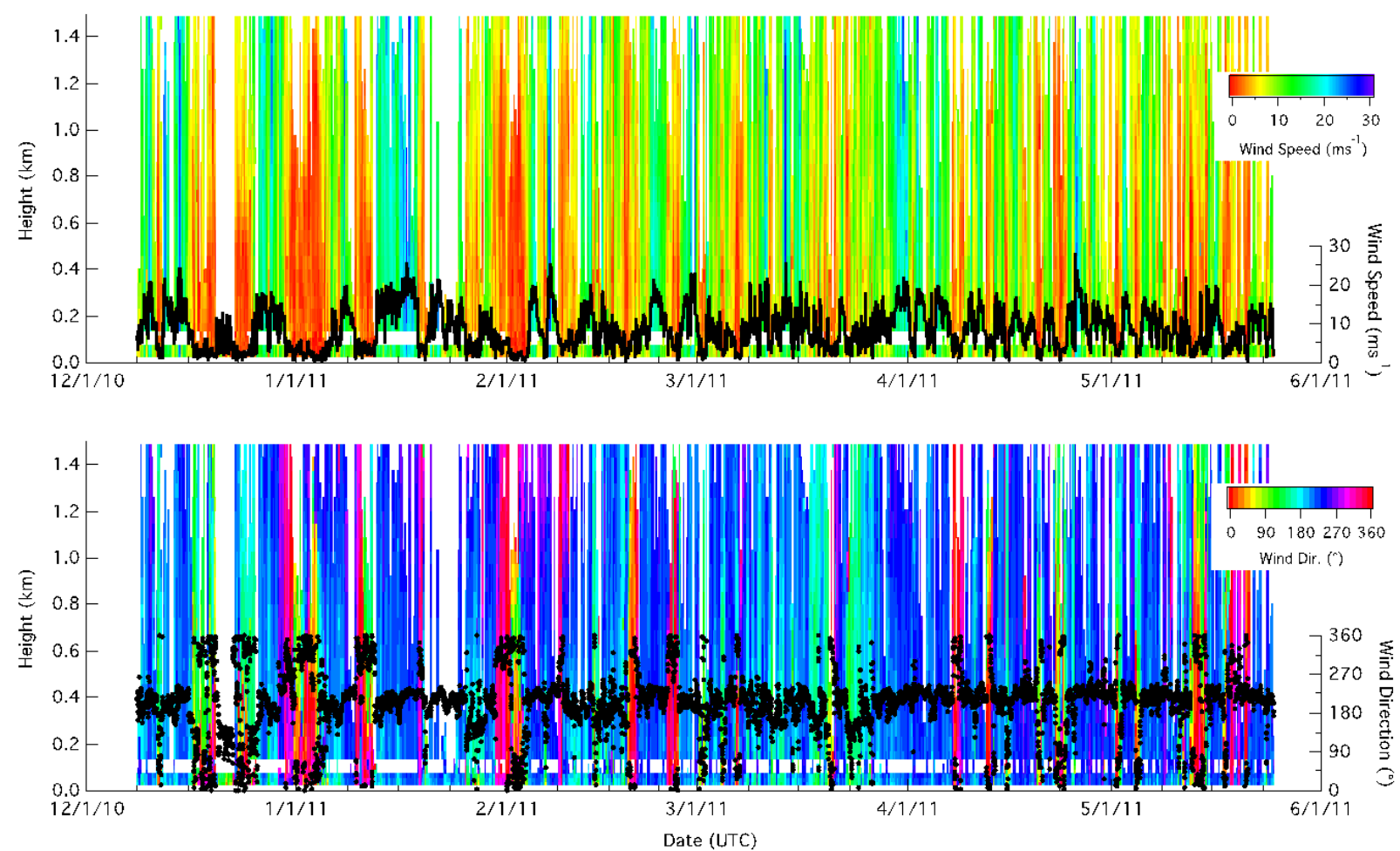

Figure 7. Time-height cross section of wind speed (top colors) and wind direction (bottom colors), along with wind speed (top-right axis, black) and wind direction (bottom-right axis, black) measured by the propeller and vane anemometer at $62 \mathrm{~m}$ (right axes). White areas indicate missing data.

\subsection{References}

Allwine K J, JH Shinn, GE Streit, KL Clawson, and M Brown. 2002. "Overview of URBAN 2000: A multiscale field study of dispersion through an urban environment." Bulletin of the American Meteorological Society 83:521-536.

Berg LK, Q Yang, MS Pekour, RK Newsom, K Johnson, C Finley, and M Stoelinga. 2013. "Using WRF to predict turbulence, wind shear, and ramp events in regions with simple and complex terrain." In preparation for the Journal of Applied Meteorology and Climatology.

Doran JC, JD Fast, and J Horel. 2002. "The VTMX 2000 campaign.” Bulletin of the American Meteorological Society 83:537-551.

Elliott DL, CG Holladay, WR Barchet, HP Foote, and WF Sandusky. 1986. Wind Energy Resource Atlas of the United States. DOE/CH10093-4, Richland, Washington.

Fast JD, RK Newsom, KJ Allwine, Q Xu, P Zhang, J Copeland, and J Sun. 2008. “An evaluation of two NEXRAD wind retrieval methodologies and their use in atmospheric dispersion models." Journal of Applied Meteorology and Climatology 47:2351-2371. 
Marquis M, J Wilczak, M Ahlstrom, J Sharp, A Stern, JC Smith, and S Calvert. 2011. "Forecasting the wind to reach significant penetration levels of wind energy." Bulletin of the American Meteorological Society 92:1159-1171.

Newsom RK, LK Berg, MS Pekour, JD Fast, Q Xu, and Q Yang. 2012. "Evaluation of wind retrievals derived from NEXRAD for wind energy applications." Journal of Applied Meteorology and Climatology., Submitted.

Poulos GS, W Blumen, DC Fritts, JK Lundquist, J Sun, SP Burns, C Nappo, R Banta, R Newsom, J Cuxart, E Terradellas, B Balsley, and M Jensen. 2002. "CASES-99: A comprehensive investigation of the stable nocturnal boundary layer." Bulletin of the American Meteorological Society 83:555-581.

Schreck S, J Lundquist, and W Shaw. 2008. U.S. Department of Energy Workshop Report: Research Needs for Wind Resource Characterization. NREL/TP-500-43521, Golden, Colorado. 


\section{Distribution}

No. of

Copies

1 Joel Cline

US DOE Wind and Water Program

1000 Independence Ave. SW

Washington, DC 20585
No. of

\section{Copies}

1 Local Distribution

Pacific Northwest National Laboratory

Larry Berg

Mikhail Pekour

Dan Nelson
(PDF)

(PDF)

(PDF)

Distr.1 


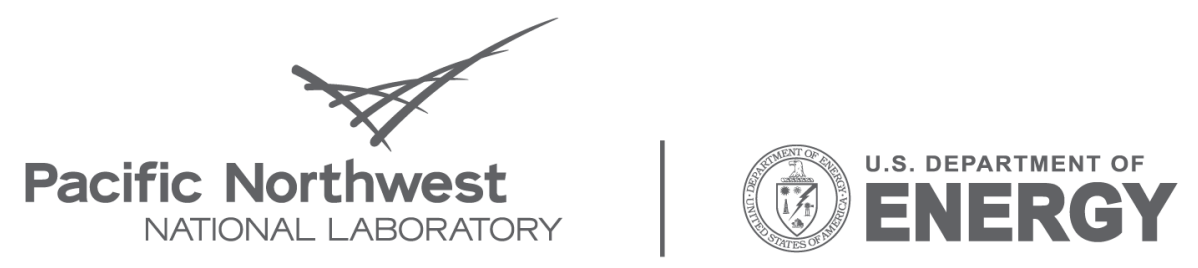

Proudly Operated by Battelle Since 1965

902 Battelle Boulevard

P.O. Box 999

Richland, WA 99352

1-888-375-PNNL (7665)

www.pnl.gov 